\title{
PRKCD wt Allele
}

National Cancer Institute

\section{Source}

National Cancer Institute. PRKCD wt Allele. NCI Thesaurus. Code C150119.

Human PRKCD wild-type allele is located in the vicinity of 3p21.1 and is approximately 37 $\mathrm{kb}$ in length. This allele, which encodes protein kinase $\mathrm{C}$ delta type protein, is involved in both cell death and cell survival. Mutation of the gene is associated with autoimmune lymphoproliferative syndrome 3. 